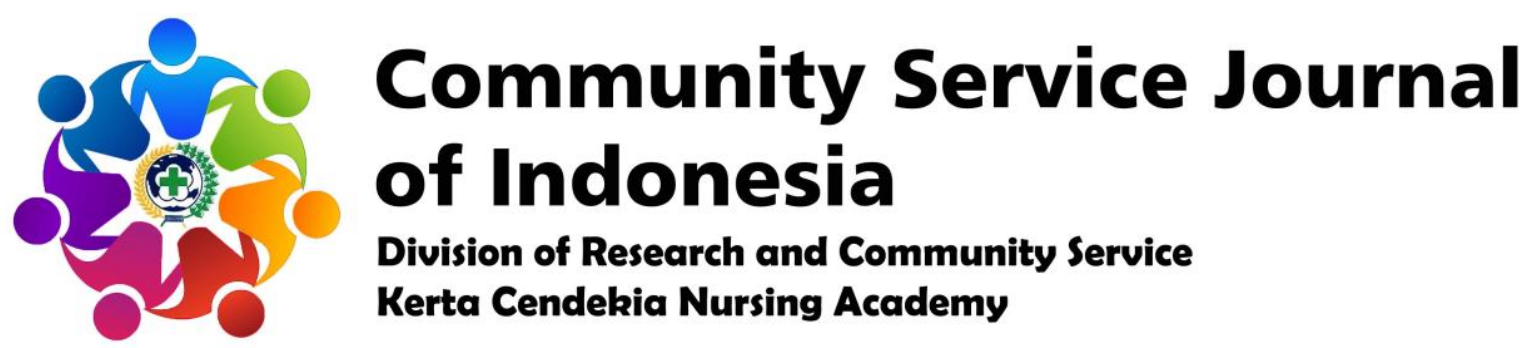

https://ejournal-kertacendekia.id/index.php/csji/index

\author{
Community Service Journal of Indonesia 2 (2) (2020): 39-42
}

Doi: https://doi.org/10.36720/csji.v2i2.256

\title{
IMPROVING COMMUNITY AWARENESS ON PREVENTION OF COVID-19 TRANSMISSION THROUGH SHARING EXPERIENCES BY NURSES AND SURVIVOR
}

\author{
Andri Setiya Wahyudi ${ }^{1}$, Candra Panji Asmoro ${ }^{1 *}$, Hakim Zulkarnain ${ }^{1}$, Achmad \\ Tirmidzi $^{2}$ \\ ${ }^{1}$ Lecturer, Faculty of Nursing, Universitas Airlangga, Surabaya \\ ${ }^{2}$ Administration staff, Faculty of Nursing, Universitas Airlangga, Surabaya \\ * Correspondence \\ Candra Panji Asmoro \\ Faculty of Nursing, Universitas Airlangga, Surabaya \\ Kampus C Mulyorejo, Surabaya, East Java Province, Indonesia - 60115 \\ Email: candra.panji.a@fkp.unair.ac.id
}

\begin{abstract}
The situation of the increasingly massive spread of Covid-19 in Indonesia has forced several countries to issue travel restrictions for their citizens entering Indonesia, as well as prohibiting Indonesian citizens from visiting their country. Health promotion is needed that can raise the awareness of Indonesian citizens to adhere to health protocols. This community service activity seeks to increase public awareness by sharing experiences from survivor and nurses of Covid-19 patients at community health services (CHS) and in field hospitals. Health promotion through webinars, which are open publicly and for free, took place on September 29, 2020. Webinars through the Zoom application and broadcast live streaming on Youtube media with the channel name "baca baca baca". The two media were chosen with the intention of making health education activities accessible to many people at any time so that the achievement of the goals could also be broader. The number of participants in Zoom media when conducting the webinar according to the previous plan is at least 50 people (54 people). The number of viewers via Youtube media exceeds the planned output of more than 100 viewers (326 people) in three months. Awareness improvement of the general public in complying with health protocols in preventing Covid-19 transmission is built through a good perception of this. Good perceptions are built through correct knowledge. The webinar method has also proven not to be an obstacle to providing health promotion to the public.
\end{abstract}

Keywords: Prevention, Covid-19, nurse, survivor.

(C) 2020 The Authors. Community Service Journal of Indonesia Published by Community Service and Research of Kerta Cendekia Nursing Academy - Kerta Cendekia Nursing Academy

This is an Open Access Article distributed under the terms of the Creative Commons Attribution 4.0 International License which permits unrestricted non-commercial use, distribution, and reproduction in any medium, provided the original work is properly cited.

E-ISSN

2684-7884 


\section{INTRODUCTION}

Currently, the coronavirus pandemic is very dangerous for human survival. This virus has not only become a pandemic in one country but has covered the world. The coronavirus is a virus that infects the human respiratory tract (Susilo, 2020). The World Health Organization (WHO) states that there are still many questions about the transmission of Corona Virus Disease 2019 or Covid-19 that have not been answered, and research aimed at answering these questions is still ongoing and is encouraged to be carried out. Current evidence indicates that Covid-19 is transmitted from person to person primarily via the airway droplet route and contact - although aerosolization in medical settings where aerosol-generating procedures are used is another possible mode of transmission - and that Covid-19 transmission occurs from people who are presymptomatic or symptomatic to others in close contact (direct or face-to-face physical contact with probable or confirmed cases within one meter for a long time), when proper PPE is not used. Transmission can also occur from an infected person who remains asymptomatic, but the extent to which this type of transmission occurs is not fully understood and needs further investigation as an urgent priority. The role and rate of transmission by air outside health-care facilities, and especially in confined spaces with poor ventilation, also need further investigation (WHO, 2020).

Every day the number of positive patients with the coronavirus is increasing. Adapted from the official social media of the National Disaster Management Agency (BNPB) as of September 24, 2020, data was obtained that the number of confirmed Covid-19 patients increased by 4,634 patients so that the total number of Covid19 sufferers nationally was 262,022 . The number of new incidents on September 24 increased from the previous day to 4,465 people. Meanwhile, the number of patients who were declared cured as of September 24 was 3,895 people with a total recovery nationally reaching 191,853 people. Meanwhile, the data from the day before (3660 / 187,958).

The Ministry of Health sees that from the situation of the spread of Covid-19 which has almost reached all provinces in Indonesia with the number of cases and/or the number of deaths increasing and having an impact on political, economic, social, cultural, defense and security aspects, as well as the welfare of the people in Indonesia. The Indonesian government has issued Presidential Decree No.11 of 2020 concerning the Determination of Covid-19 Public Health Emergencies. The Presidential Decree determined Covid-19 as a type of disease that caused a Public Health Emergency (KKM) and determined the Covid-19 KKM in Indonesia, which must be made in accordance with the provisions of laws and regulations. In addition, considering the spread of Covid-19 has an impact on increasing the number of victims and property losses, widening the coverage of the affected areas, as well as having implications for broad socio-economic aspects in Indonesia, Presidential Decree No.12 of 2020 concerning the Determination of Non-Deployment Disasters has also been issued. Covid-19 As a National Disaster (Ministry of Health, 2020).

As scientists continue to carry out various studies to better understand this virus and come up with a cure, we are working to raise public awareness by 
strengthening people's perceptions that the virus is still there and that the number of people infected is growing. Therefore, sharing knowledge in webinars regarding the experience of caring for Covid-19 patients and the experiences of sufferers who have recovered from Covid-19 can foster active participation from webinar participants to comply with health protocols and comply with central or regional government regulations that have been made regarding the prevention of transmission. this virus.

\section{OBJECTIVES}

\section{General Purpose}

After 50 minutes of the webinar, it is hoped that the participants can understand the severity if infected by Covid-19, especially in patients with chronic comorbid diseases that the patient has previously had.

\section{Special Purpose}

After 50 minutes of the webinar, it is hoped that the participants have a positive perception about health protocol to prevent the spreading of Covid-19, and then have the awareness to comply with health protocols and other restrictions regulated by the central or regional government.

\section{PLAN OF ACTION}

Strategy Plan

The strategy plan implemented, including:

1. Coordinate with the Dean of Faculty of Nursing, Universitas Airlangga to apply for permission to implement health education so the team can held the webinar using the facilitation at the Faculty of Nursing such as internet connection and the account of Zoom edu.
2. Establish time contracts with all of interviewees.

3. Make announcement at the social media about the webinar.

4. Conducting the webinar.

\section{Implementation}

Actions taken in the implementation of these activities, including:

1. Collected all health education materials of the interviewees.

2. Prepared an account of zoom edu and linked with the Youtube channel "baca baca baca".

3. Delivery of health education materials tothe all of participants.

\section{Setting}

This activity was carried out at online webinar on September 29, 2020 at 1-3 pm.

Target

Target in this activity is all of the general public who have interest to gained the knowledge about why we have to improving the compliance of health protocol in pandemic era.

\section{RESULTS AND DISCUSSION}

This activity took place on September 29, 2020, which lasted for two hours starting at 1 to $3 \mathrm{pm}$. Activities carried out according to plan. The interviewees of this webinar are Mr. Candra Panji Asmoro as the survivor of Covid-19, Mr. Dady Zharfan as the nurse volunteer who worked at the field hospital at Surabaya, and Mr. Rendra Pramudya as the nurse who worked at the community health service at the Kebumen, West Java. This activity was attended by 54 participants who joined live at zoom, and more than 20 participants who had joined in streaming Youtube. All of the participants seemed 
enthusiastic in the process of delivering online health education that was held at the webinar. This was done when the Covid19 pandemic was still ongoing and we needed innovation so that the delivery of this important information could add insight to the public. Public perception becomes positive after participating in the webinar. This was indicated by the presence of several questions asked by the participants, the number of participants who attended in person and online both on Zoom media and on Youtube exceeded expectations. In the end, we had delivered the webinar's material and certificate to all of the participants, interviewees, and committee. The certificate had signed by the Dean of Faculty of Nursing, Universitas Airlangga. The media used in this health education include laptops, powerpoints, internet connection, flyers for promotion of the agenda in social media, Zoom edu account, and Youtube channel that we used is "baca baca baca". We are promoting this webinar activity agenda for a week before the activity is held.

\section{CONCLUSION}

Awareness of improvement of the general public in complying with health protocols in preventing Covid-19 transmission is built through a good perception of this. Good perceptions are built through correct knowledge. This online webinar is not an obstacle for us to share this knowledge.

\section{REFERENCES}

Susilo, A. d. (2020). Coronavirus Disease 2019 : Tinjauan Literatur Terkini. Jurnal Penyakit Dalam Indonesia, Vol 7 (1), page 45-67.
Kemenkes, 2020. Buku Pedoman P2 Covid-19 Revisi 5. Diakses di https://covid19.kemkes.go.id/down load/REV-

05_Pedoman_P2_COVID-

19_13_Juli_2020_1.pdf accessed at the September 24, 2020, at 8.55 pm.

WHO, 2020. Transmisi SARS-CoV-2: implikasi terhadap kewaspadaan pencegahan infeksi. Diakses di https://www.who.int/docs/defaultsource/searo/indonesia/covid19/tra nsmisi-sars-cov-2---implikasiuntuk-terhadap-kewaspadaanpencegahan-infeksi---pernyataankeilmuan.pdf?sfvrsn=1534d7df_4 accessed at the September 24, 2020 , at $8.55 \mathrm{pm}$. 